\title{
THE COMMUNITY INNOVATION SURVEY AND THE INNOVATION PERFORMANCE OF ENTERPRISES FUNDED BY EU'S FRAMEWORK PROGRAMMES
}

JESÚS ALQUÉZAR SABADIE AND CLAIRE KWIATKOWSKI

\section{ABSTRACT}

$\mathrm{T}$ he Horizon 2020 monitoring and evaluation system has been improved in recent years, but there is still a need to further develop the ways to measure innovation outputs, outcomes and impacts. At present, project reporting provides only a few innovationrelated indicators. This paper shows that the Eurostat's Community Innovation Survey (CIS) could be a valuable source of information to assess those issues.

The analysis of the CIS 2008, 2010 and 2012 demonstrates that innovative enterprises financed by the 7th Framework Programme (FP7) performed significantly better in terms of exploitation of products, services and processes. The data allow characterising the successful FP7 innovators: large enterprises perform slightly better, and there are significant differences by sector and by country. FP7 funding seems to play a cohesive role amongst countries, as a consequence of cooperative research and innovation activities. Innovative firms supported by FP7 deliver more environmental-friendly innovations and obtain better turnovers from their innovations

While the CIS could be a useful tool to assess the innovation impacts of the Framework Programmes, there are also some issues to keep in mind. In particular, the design of the questionnaire does not allow for an analysis of a full impact of all FP7 participants: the FP7 had a worldwide participation, while the CIS is limited to the EU respondents. Moreover, confidentiality rules lead to information loses when more than two variables are cross-referenced or when very detailed data (e.g. by NACE beyond one digit) are extracted. Finally, it is important to remember that correlations do not mean causality.

The free and easily accessible CIS data provides a good opportunity to go further in the evaluation of innovation impacts of European framework programmes.

\section{BACKGROUND: INNOVATION AND IMPACT IN HORIZON 2020}

Innovation is one of the key objectives of the ongoing European Union's Framework Programme for Research and Innovation, Horizon 2020 (2014-2020). The EU Regulation 1291/2013 establishes as general objective of Horizon 2020 "(...) to contribute to building a society and an economy based on knowledge and innovation across the Union by leveraging additional research, development and innovation funding and by contributing to attaining research and development targets (...)" (article 5,§1) .

Innovation is not new in the history of the FPs, but it gained a special importance as a response to the global economic crisis that started in $2007^{2}$. The initial main objective of the Seventh Framework Programme of the European Community for research, technological development and demonstration activities (FP7, 2007-2013), the Horizon 2020 predecessor $^{3}$, was to implement the European Research Area (ERA). In that sense, FP7 was tasked to: (i) promote transnational cooperation; (ii) promote investigator-driven basic research based on excellence; and (iii) develop the human potential in research and technology, thereby "...encouraging researchers' mobility and career development..."4 Concerning innovation, FP7 was initially supposed to complement other EU funding schemes, such as the Competitiveness and Innovation Programme $(\mathrm{CIP})^{5}$

The FP7 orientation changed as a political response to the crisis. In November 2008, the Commission then led by President Durao Barroso launched its Economic Recovery Plan ${ }^{6}$. The document emphasised the need for smart investments, especially on clean technologies, to boost the economy and promote innovation. This narrative was further developed in the Europe 2020 Strategy, which defended a "smart, sustainable

Regulation 1291/2013 of 11 December 2013 of the European Parliament and the Council establishing Horizon 2020 - the Framework Programme forResearch and Innovation (2014-2020), at: http://eur-lex.europa.eu/LexUriServ/LexUriServ.do?uri=0J:L:2013:347:0104:0173:EN:PDF

What follows is based on Connolly et al. (2014).

Note the different terminology used in the official FP7 and Horizon 2020 names. FP7 was about "research, technological development and demonstration" while Horizon 2020 focuses on "research and innovation". Innovation is for the first time explicitly mentioned in the name of the programme. Decision 1982/2006 of the European Parliament and the Council of 18 December 2006 concerning the Seventh Framework Programme of the European Community for research, technological development and demonstration activities (2007-2013), Preamble, recital (8). Ibid, Preamble, recital (22)

Communication from the European Commission (2008) A European Economic Recovery Plan, COM (2008)800 final. 
and inclusive growth" concept for Europe. The "smart" component explicitly refers to "knowledge and innovation as drivers of future growth"7.

Last but not least, the Innovation Union flagship initiative, as part of the Europe 2020 strategy, highlighted the need for action at EU level to develop a strategic approach to research and innovation (RgI). The Commission stated that innovation is "... our best means of successfully tackling major societal challenges, such as climate change, energy and resource scarcity, health and ageing, which are becoming more urgent by the day"8. The Commission sometimes presents Horizon 2020 as "the financial instrument implementing the Innovation Union, a Europe 2020 flagship initiative aimed at securing Europe's global competitiveness" ${ }^{\prime 9}$.

This historical background explains the strong focus of the current Framework Programme, Horizon 2020, on innovation. Innovation is seen as a solution to address the economic crisis, while tackling major societal challenges. This idea is at the core of the rationale of Horizon 2020.

The Commission has the legal obligation to evaluate the results of the Framework Programmes. However, assessing the impact of R\&l is more important than ever in Horizon 2020, which regulation contains many references like "achieve maximum impact", "achieving the greatest possible impact" or "maximise impact". This is further developed in the Council Decision establishing the specific programme implementing Horizon 2020 ("Specific Programme")" an Annex with "performance indicators". Some few relate to innovation:

- Patent applications and patents awarded in Future and Enabling Technologies, in the different enabling and industrial technologies and in the various societal challenges (i.e. under the three Horizon 2020 main priorities: "Excellent Science", "Industrial Leadership" and "Societal Challenges").

- Share of participating firms introducing innovations new to the company or the market (covering the period of the project plus three years), under the priority "Industrial Leadership".

- Number of prototypes and testing activities, under the priority "Societal Challenges".

For the Horizon 2020 monitoring and evaluation, the compulsory performance indicators represent an improvement compared with previous Framework Programmes. Positive developments have occurred in recent years, for example through the creation of RESPIR, the Commission database on Ryl projects' outputs ${ }^{11}$. However, there is a constant need to enhance the evaluation and monitoring system of the Framework Programmes. The High Level Expert Group for the Ex Post Evaluation of FP7 observed and recommended that "(...) evaluation activities have been considered as routine activities in recent years (...). Considering that the Framework Programme have consistently been the third largest bud- get of the European Union, a strategic and professional monitoring and evaluation system is required that increases transparency and serves as a comprehensive and trusted source of evidence-based decision making" (Martinuzzi et al. 2015, p.9).

This diagnosis is not new for the Commission services dealing with monitoring and evaluation of the Framework Programmes. Other previous evaluation exercises reached similar conclusions. For instance, the Ex Post Evaluation of FP7- Cooperation Theme: Environment /including Climate Change) recommended the Commission to enhance its monitoring system, especially in the areas of innovation and policy use of results. The authors of this assessment said that "the Commission [should be able] to identify innovative projects with potential societal impacts, as well as their strengths and weaknesses, to provide further support (if needed) and facilitate networking with complementary projects, and dissemination. For innovation issues, the monitoring system should rely on a set of smart indicators (...) and on insights from Project Officers" (Connolly et al. 2014, p.79).

Nevertheless, the management of Horizon 2020 is confronted to a paradox. Innovation is one of the core issues that the programme should address (it was indeed judged as the key European weakness to push for growth and to address societal challenges in the Horizon 2020 Ex Ante Impact Assessment ${ }^{12}$ ), but it remains weakly monitored. It would be very relevant for the Commission to explore new tools to follow-up systematically and comprehensively the innovation results of projects and their impacts. There is still a need to collect basic information on innovation outputs and outcomes, like Technology Readiness Level (TRL) attained, barriers encountered to commercialise or exploit results, health/energy/resource efficiency/climate impacts of innovations (e.g. reduction of emissions, saving of energy or raw materials), commercialisation data or further investments committed. It is increasingly necessary to measure the creation of economic value and impacts of projects, in order to answer the following questions: What are the economic returns of participating in Horizon 2020? Is participation paying off economically?

How can the Commission assess basic economic (and environmental) impacts of Horizon 2020? This question is now politically critical, because of the strong focus of the current President Juncker Commission on growth, jobs and investment ${ }^{13}$. In this context, EU-funded Ryl must demonstrate its impact and contribution to such economic goals, in a time when austerity measures strongly affect research funding in several European countries.

Communication from the European Commission (2010) Europe 2020: A strategy for smart, sustainable and inclusive growth, C0M (2010)2020 final. Communication from the European Commission (2010) Europe 2020 Flagship Initiative Innovation Union, COM (2010) 546 final.

See the Horizon 2020 website, at: https://ec.europa.eu/programmes/horizon2020/en/what-horizon-2020

Council Decision of 3 December 2013 establishing the specific programme implementing Horizon 2020 - the Framework Programme for Research and Innovation (2014-2020).

1 RESPIR stands for RESearch Performance and Impact Reporting tool. In includes data on publications, Intellectual Property Rights (IPRs), dissemination activities and workforce statistics, based on projects' reporting. Before the last years of FP7, those data were collected, but never handled and aggregated in a common and harmonise database. Evaluation studies used to launch new surveys to collect information on concrete outputs from projects.

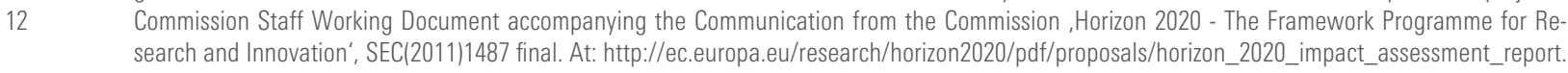
pdf

13 See: https://ec.europa.eu/priorities/index_en 


\section{THE COMMUNITY INNOVA- TION SURVEY AND THE FRAME- WORK PROGRAMMES}

The main source of information on Rql outputs and outcomes is projects' reporting. The simplification principle guides the whole Horizon 2020 implementation. It implies that the extent and content of reporting is rather limited under this Framework Programme. In its response to the recommendations of the High Level Expert Group for the Ex Post Evaluation of FP7, the Commission commits to "establish data links with external databases to complete and improve the quality of data sets"14. Solutions and alternative data sources must be therefore explored and used to assess the innovation results and impacts of Horizon 2020 projects.

Eurostat launched its first Community Innovation Survey (CIS) in 1992. This bi-annual large scale survey provides harmonised data on enterprises' innovation activities and results by sector, size of company, type of innovation and the various stages of the innovation process: objectives, sources of information, investments, public funding, etc. The CIS is carried out in all Member States and other associated countries, but not all of them allow accessing to the raw data through Eurostat. For example, the CIS 2012 made data accessible for 13 EU Member States plus Norway ${ }^{5}$, with 143,669 enterprises covered.

The CIS questionnaire includes an item that refers to funding from the Framework Programme ${ }^{16}$ :

During the three years 2010 to 2012, did your enterprise receive any public financial support for innovation activities from the following levels of government? IInclude financial support via tax credits or deductions, grants, subsidised loans, and loan guarantees. Exclude research and other innovation activities conducted entirely for the public sector under contract).

- Local or regional authorities - Yes/No

- Central government lincluding central government agencies or ministries) - Yes/No

- The European Union (EU) - Yes/No

- If yes, did your enterprise participate in the EU 7th Framework Programme for Research and Technical Development? - Yes/No

The last question (indicator FUNRTD in Eurostat's nomenclature) is very relevant for evaluating FP7 outcomes and impacts. It allows identifying in an aggregated way, within the CIS respondents, enterprises that received FP7support.This makes it possible to perform a counter-factual analysis, comparing results of companies that received FP7 funding with those that did not (but could benefit from other financial support, local, regional or European). The CIS data also permit to understand which factors and barriers influence innovation outcomes, both for FP7-funded enterprises and overall.

Despite a large scientific literature that exploits the CIS, especially at national level, the Commission services have rarely used it to evaluate the EU's Framework Programmes. The European R\&l policy community largely relies on traditional indicators, like publications and patents, insufficient to capture innovation. Indeed, academic analysis of the CIS has had little impact on the European innovation policy (Arundel 2007). There are however some exceptions. In 2009, a PRO-INNO report combined the analysis of CIS with ad-hoc surveys and case studies to conclude that "the Framework Programme attracts the highly innovative companies and research institutions in Europe". The participants were more R\&D intensive, more networked and more internationalised than the average. They obtained higher returns on innovative sales (Fisher, Polt \& Vonortas 2009, p.7-8). The study referred to FP4 (1994-1998) and FP5 (1998-2002). Muldur et al. (2006) reached similar conclusions in 2006, using the CIS 3 (1998-2000).In 2013, a Science-Metrix study on Small and Medium Enterprises (SMEs) innovation performance used the CIS 2010 to design and test an ad-hoc survey questionnaire (Hassan et al. 2013).

Using the CIS for evaluation purposes presents nevertheless some caveats:

- Geographical coverage: Not all EU Member States make their CIS raw data available, while the FPs are open to the world. All countries can participate in Horizon 2020, with different status and under different conditions: Member States, candidate countries, associated countries, developed or emerging third countries, developing third countries. Therefore the available $\mathrm{CIS}$ raw data give an incomplete picture of the innovative firms involved in the Framework Programmes.

- Timeframe: The CIS is a bi-annual survey ${ }^{17}$, which dates do not necessarily coincide with the starting and ending years of the FPs. For example, FP7 ran from 2007 to 2013. The CIS 2008 covered years 2006 to 2008; therefore its FUNRTD variable referred to both FP6 and FP7. Similarly, the CIS 2012 went from 2010 to 2012 and thus lets out the last year of FP7, 2013. It is important to point out, indeed, that almost half of the FP7 projects were still running when the programme was replaced by Horizon 2020 in 2014. These projects will provide their main outcomes and impacts long time after 2013.

- Issues related to the questionnaire design: There are typically five types of innovation: on product, service, process, organisational and marketing. Due to its position in the questionnaire, the item on FP7 support just covers the three first categories. In addition, the FP7-related question is filtered. Only enterprises that declared having introduced during the last three years any product, service or process innovation or, at least, having been involved on any innovation activity abandoned or still ongoing, were allowed to answer the question on FP7 funding. This means that only innovative companies supported by FP7 can be analysed; FP7-funded enterprises not involved in innovations cannot be identified. Even if we could expect that private for profit organisations' main motivation to participate in FPs may

\footnotetext{
14 Communication from the European Commission(2016) Communication on the Response to the Report of the High Level Expert Group on the Ex Post Evaluation of the Seventh Framework Programme, COM (2016)5 final, p.9.

15 See: http://ec.europa.eu/eurostat/web/microdata/community-innovation-survey. The CIS 2012 methodology is explained in detail at: http://ec.europa. eu/eurostat/cache/metadata/en/inn_cis8_esms.htm

$6 \quad$ Question 5.3 in CIS 2012.

17 The CIS is bi-annual since 2007. The first four editions covered three-years-time intervals. The story of the CIS can be read in Hassan, E. et al. (2013), from p. 12.
} 
be precisely innovation, we cannot assume a priori that the CIS sub-sample of FP7-financed enterprises is a representative subsample of all companies that benefit from FP7. The CIS allows to analyse innovative enterprises supported by FP7, but not necessarily all enterprises supported by FP7.

- Anonymisation of respondents: The CIS must comply with strict confidentiality rules. This is an issue for researchers and analysts, who cannot merge the data with other sources (e.g. internal database of the European Commission on FP projects, CORDA) and cannot track firms over time. Thus it is difficult to analyse the circular link between policy, R\&D, innovation and performance (Mazzanti et al. 2016).

- Problems of the eco-innovation module: The CIS 2008 included a voluntary eco-innovation module, whose next edition is foreseen in CIS 2014. It provides useful information about environment-friendly innovations introduced by enterprises and why they were implemented. The purposes of the eco-innovation are very focused on policy aspects: regulations, taxes, public support or voluntary codes. There is just one item on economic aspects ("current or expected market demand from your customers for environmental innovation"). Although this information is precious, it hinders some relevant aspects like the economic mitivations (cost reduction, productivity growth, competitive advantage, etc.). Ethical considerations, like companies that develop environment-friendly innovation for ethical reasons, are neither taken into account. Last but not least, the filters of the questionnaire allow analysing a sub-sample of ecoinnovative enterprises, but nothing is known about how regulation influences the behaviours of non-eco-innovative firms (Mazzanti et al. 2016).

Despite these caveats, the CIS is a very relevant source of information to assess and analyse the innovation results of the Framework Programmes. This is the purpose of this paper. The authors use data from the CIS 2008, 2010 and $2012^{18}$ and try to answer to the following questions: Do enterprises supported by FP7 perform better than the average? Are there significant differences by country, sector, size of enterprise, source of financing, etc.? What are the economic returns of exploited innovations? The analysis focuses on FP7 funding but aims at demonstrating the opportunity for the Commission services of exploiting the CIS data systematically to assess innovation results and impacts of the Framework Programmes. From the European Commission perspective, the final goal of the analysis is to extract concrete and operational lessons from FP7 which can be used for the Interim Evaluation of Horizon 2020.

The paper looks also at the results of the Eco-Innovation module proposed at the CIS 2008 and links its results with the general innovation trends. This is particularly relevant in the context of the Circular Economy strategy of the EU, which must be monitored too ${ }^{19}$.

\section{DO INNOVATIVE ENTERPRISES SUPPORTED BY FP7 PERFORM BETTER IN TERMS OF ECONOMIC OUTPUTS?}

We consider that enterprises perform better in terms of innovation when they:

- Introduce a new or significantly improved product to the market before their competitors do (variable NEWMKT).

- Introduce a new or significantly improved product to the firm, which was already available from competitors in the reference market (variable NEWFRM).

- Introduce new or significantly improved process innovations (i.e. methods of manufacturing or producing goods and services; logistics, delivery or distribution methods for inputs, goods or services; or supporting activities for processes, such as maintenance systems or operations for purchasing, accounting or computing), new to the market (variable INPSNM).

Therefore this analysis uses the exploitation of innovations as a performance indicator. It does not look at the advancement in the innovation process, i.e. from a Technology Readiness Level (TRL) to another.

Table 1 compares the innovation performance of innovative enterprises that benefitted from FP7 funding with those that did not.

Table 1: Innovation performance: Firms supported by FP7 vs. not supported

\begin{tabular}{|c|c|c|c|c|}
\hline \multicolumn{5}{|c|}{ CIS 2008 (2006-2008) } \\
\hline & $\begin{array}{l}\text { Supported } \\
\text { by FP7 }\end{array}$ & $\begin{array}{l}\text { Non- } \\
\text { supported } \\
\text { by FP7 }\end{array}$ & $\begin{array}{l}\text { Significance } \\
\text { Chi-square }\end{array}$ & $\begin{array}{l}\text { Phi } \\
\text { coefficient }\end{array}$ \\
\hline $\begin{array}{l}\text { New to the market } \\
\text { product or service } \\
\text { innovations (NEWMKT) }\end{array}$ & $\begin{array}{c}1,132 \\
73.36 \%\end{array}$ & $\begin{array}{l}13,376 \\
42,67 \%\end{array}$ & $<0.0001$ & 0.13 \\
\hline $\begin{array}{l}\text { New to the firm product } \\
\text { or service innovations } \\
\text { (NEWFRM) }\end{array}$ & $\begin{array}{c}1,082 \\
71.14 \%\end{array}$ & $\begin{array}{l}17,554 \\
56.02 \%\end{array}$ & $<0.0001$ & 0.064 \\
\hline $\begin{array}{l}\text { New to the market } \\
\text { process innovations } \\
\text { (INPSNM) }\end{array}$ & $\begin{array}{c}357 \\
39.23 \%\end{array}$ & $\begin{array}{l}3,471 \\
19.8 \%\end{array}$ & $<0.0001$ & 0.106 \\
\hline \multicolumn{5}{|c|}{ CIS 2010 (2008-2010) } \\
\hline $\begin{array}{l}\text { New to the market } \\
\text { product or service } \\
\text { innovations (NEWMKT) }\end{array}$ & $\begin{array}{c}1.076 \\
79.79 \%\end{array}$ & $\begin{array}{l}11,575 \\
31.59 \%\end{array}$ & $<0.0001$ & 0.186 \\
\hline $\begin{array}{l}\text { New to the firm product } \\
\text { or service innovations } \\
\text { (NEWFRM) }\end{array}$ & $\begin{array}{c}917 \\
70.38 \%\end{array}$ & $\begin{array}{r}15,299 \\
41.72 \%\end{array}$ & $<0.0001$ & 0.106 \\
\hline $\begin{array}{l}\text { New to the market } \\
\text { process innovations } \\
\text { (INPSNM) }\end{array}$ & $\begin{array}{c}362 \\
49.05 \%\end{array}$ & $\begin{array}{c}3,048 \\
12.83 \%\end{array}$ & $<0.0001$ & 0.203 \\
\hline
\end{tabular}




\begin{tabular}{|l|c|c|c|c|}
\hline \multicolumn{5}{|c|}{ CIS 2012 (2010-2012) } \\
\hline $\begin{array}{l}\text { New to the market } \\
\text { product or service } \\
\text { innovations (NEWMKT) }\end{array}$ & $\begin{array}{c}1.191 \\
78.51 \%\end{array}$ & $\begin{array}{c}10,144 \\
43.38 \%\end{array}$ & $<0.0001$ & 0.169 \\
\hline $\begin{array}{l}\text { New to the firm product } \\
\text { or service innovations } \\
\text { (NEWWFRM) }\end{array}$ & $\begin{array}{c}943 \\
66.74 \%\end{array}$ & $\begin{array}{c}13,821 \\
59.38 \%\end{array}$ & $<0.0001$ & 0.035 \\
\hline $\begin{array}{l}\text { New to the market } \\
\text { process innovations } \\
\text { (INPSNM) }\end{array}$ & $\begin{array}{c}378 \\
42.81 \%\end{array}$ & $\begin{array}{c}2,732 \\
18.83 \%\end{array}$ & $<0.0001$ & 0.156 \\
\hline
\end{tabular}

FP7-funded innovative enterprises perform significantly better than those not supported. Between 2006 and 2012, more than 70\% of the firms that benefitted from FP7 funding introduced new products to the market, while others remained under $45 \%$. The difference is less pronounced - but still very strong - when referring to products new to the firm only, while new to the market process innovations present lower figures (below 50\% in all CIS 2008, 2010 and 2012) that anyway double those of enterprises not supported by FP7.

Of course, the significant correlations between FP7 participation and innovation performance do not necessarily mean causality. It could be assumed that the Framework Programmes attract Ryl-intensive organisations, which are expected to be more innovative than the average.

Indeed, FP7 was a RYI programme focused on excellence, with a very low success rate of applications $(18.7 \%)^{20}$. Beneficiaries needed to have very strong capacities to be selected by independent evaluators. Amongst the main FP7 beneficiaries we find the biggest European Ryl organisations, such as the Centre National de la Recherche Scientifique (CNRS, France), Fraunhofer (Germany), the universities of Cambridge and Oxford, the Commissariat à I'Energie Atomique et aux Energies Alternatives (CEA, France) or the German Max Plank Institute. Amongst private for profit organisations, the ranking (by EU contribution received) is led by Geant Limited (UK, on water transport), SAP (Germany, ICT), Thales, Siemens, etc. The top European firms in terms of R\&D investment appear also in the list of FP7 participants ${ }^{21}$

Therefore Table 1 does not allow to conclude that firms financed by FP7 obtain better innovation results because of their participation in the programme. However, FP7 was at least likely to attract the most Ryl intensive enterprises, which in turn improve their capacities thanks to collaboration in Ryl at international level. The logic is likely to be circular, not linear.

The main differences between FP7-funded firms and enterprises not supported by the EU's Framework Programme appear for new to the market product and services innovations, and for new to the market processes. This indicates that FP7 led primarily to the development and implementation of novel products, services and processes and not to replicate or improve those that were already in the market. The opposite could be considered as a failure for a Ryl programme.

The results presented in Table 1 hide differences by sector, size of enterprise and country. Not all enterprises that participate in FP7 obtain similar results.

\subsection{INNOVATION PERFORMANCE, BY SIZE OF ENTER-} PRISE

The Horizon 2020 Regulation considers that "SMEs [micro, Small and Medium-sized Enterprises] constitute a significant source of innovation, growth and jobs in Europe"22 and provides different specific instruments to push for innovation in SMEs. It is therefore very relevant to breakdown the innovation results of European enterprises by size, comparing those funded by FP7 with other firms.

This analysis distinguishes micro, small and medium enterprises based on the number of employees and the turnover criteria: Micro SMEs are those with less than 10 employees and $€ 2,000,000$ turnover or less; Small SMEs employ less than 50 people and their turnover is lower or equal to $€ 10,000,000$; Medium SMEs have less than 250 employees and no more than $€ 50,000,000$ of turnover. Beyond these limits, enterprises are considered "large". These categories follow the European Commission's definition, which however adds a criterion based on the balance sheet ${ }^{23}$, not considered here because not covered by the CIS.

Table 2 shows the breakdown of enterprises that received support from FP7 and declared being involved in innovation activities, by size. As a reference, $55 \%$ of private-for profit organisations that participated in FP7 were SMEs.

Table 2: FP7-funded enterprises with innovation activities, by size (\%)

\begin{tabular}{|l|l|l|l|l|l|}
\hline & Micro & Small & Medium & Large & N \\
\hline CIS 2008 & $8.58 \%$ & $26.47 \%$ & $30.62 \%$ & $34.32 \%$ & 1,783 \\
\hline CIS 2010 & $7.80 \%$ & $29.40 \%$ & $26.15 \%$ & $36.65 \%$ & 1,629 \\
\hline CIS 2012 & $6.47 \%$ & $28.83 \%$ & $26.62 \%$ & $38.07 \%$ & 1,807 \\
\hline
\end{tabular}

Does the size of enterprises matter in terms of innovation performance (i.e. exploitation of innovations)? - Annex 2 presents the contingency tables that help to answer this question, for CIS 2008, CIS 2010 and CIS 2012. They focus on new to the market and new to the firm products and services (variables NEWMKT and NEWFRM). Tables for the variable INPSNM ("new to the market process innovations") are not used, because of the large number of data missing due to the CIS' confidentiality rules.

The CIS data show that large innovative companies perform better in introducing new to the market products or services (variable NEWMKT). This trend appears in all three CIS editions, for both FP7-funded and not funded enterprises, except in CIS 2010 for FP7-supported enterprises. For instance, in CIS 2008, 79\% of large innovative enterprises funded by FP7 introduced a new product or service to the market, while the figures for SMEs were around 70\%. In 2012, the differences were much lower $(82.4 \%$ versus $79.6 \%$ for micro SMEs) and even statistically insignificant in 2010.

Amongst FP7-funded enterprises, most new to the market innovations come from large companies, while small SMEs present the biggest figure for non-FP7-financed firms. This is not surprising. Small SMEs constitute the largest share of non-FP7-financed innovative enterprises, proposals and only 25,363 were selected for funding. 
while large companies are the most numerous amongst firms participating in the programme.

Concerning new to the firm innovations, the best performing enterprises supported by FP7 are large and micro ones. Differences by size are nevertheless minor.

The size of the enterprises influences different levels of innovation outputs, but it is not a critical factor: Phi and contingency coefficients are low, between $4 \%$ and $16 \%$. Differences are therefore small and sometimes even statistically insignificant. In any case, large firms tend to perform slightly better in terms of introducing products and services new to the market. Companies supported by FP7 obtain always better innovation outcomes, irrespective of the size of the enterprise.

\subsection{INNOVATION PERFORMANCE, BY COUNTRY}

Some countries perform significantly better than others in terms of exploitation of innovations. Indeed, the variable "country" influences more the introduction of new products, services or processes to the market or the firm than the size of enterprises. Table 3 presents the contingency and Phi coefficients of cross-tables between countries and NEWMRKT, NEWFRM and INPSNM variables. In all cases, the correlation is statistically significant and its degree of association much higher than those obtained for size of enterprise.
Table 3: Degree of association country-exploitation of innovation variables

\begin{tabular}{|c|c|c|c|}
\hline & $\begin{array}{l}\text { New to the market } \\
\text { product or service } \\
\text { innovations (NEWMKT) }\end{array}$ & $\begin{array}{l}\text { New to the firm product } \\
\text { or service innovations } \\
\text { (NEWFRM) }\end{array}$ & $\begin{array}{l}\text { New to the market } \\
\text { process innovations } \\
\text { (INPSNM) }\end{array}$ \\
\hline \begin{tabular}{|l|} 
CIS \\
2008
\end{tabular} & $\begin{array}{l}\text { Sign. Chi-square }<0.0001 \\
\text { Phi coeff.: } 40.37 \% \\
\text { Contingency } \\
\text { coeff.: } 37.43 \%\end{array}$ & $\begin{array}{l}\text { Sign. Chi-square }<0.0001 \\
\text { Phi coeff.: } 53.97 \% \\
\text { Contingency } \\
\text { coeff.: } 47.49 \%\end{array}$ & $\begin{array}{l}\text { Sign. Chi-square }<0.0001 \\
\text { Phi coeff.: } 69.79 \% \\
\text { Contingency } \\
\text { coeff.: } 57.23 \%\end{array}$ \\
\hline \begin{tabular}{|l|} 
CIS \\
2010
\end{tabular} & $\begin{array}{l}\text { Sign. Chi-square }<0.0001 \\
\text { Phi coeff.: } 43.95 \% \\
\text { Contingency } \\
\text { coeff.: } 40.23 \%\end{array}$ & $\begin{array}{l}\text { Sign. Chi-square }<0.0001 \\
\text { Phi coeff:: } 56.37 \% \\
\text { Contingency coeff:: } 49.1 \%\end{array}$ & $\begin{array}{l}\text { Sign. Chi-square }<0.0001 \\
\text { Phi coeff.: } 48.57 \% \\
\text { Contingency } \\
\text { coeff:: } 43.69 \%\end{array}$ \\
\hline $\begin{array}{l}\text { CIS } \\
2012\end{array}$ & $\begin{array}{l}\text { Sign. Chi-square }<0.0001 \\
\text { Phi coeff.: } 46.45 \% \\
\text { Contingency } \\
\text { coeff.: } 42.27 \%\end{array}$ & $\begin{array}{l}\text { Sign. Chi-square }<0.0001 \\
\text { Phi coeff.: } 52.51 \% \\
\text { Contingency } \\
\text { coeff:.: } 46.49 \%\end{array}$ & $\begin{array}{l}\text { Sign. Chi-square }<0.0001 \\
\text { Phi coeff.: } 48.78 \% \\
\text { Contingency } \\
\text { coeff:: } 43.84 \%\end{array}$ \\
\hline
\end{tabular}

Figure 1 illustrates the difference performance of countries, either when "their" enterprises receive FP7 funding or not. Unfortunately, due to confidentiality rules, the contingency tables between implemented innovations and countries controlled by FP7 funding cover only few countries: 11 in the CIS 2008, 7 in CIS 2010 and 9 in CIS 2012, when referring to new to the market products and services (NEWMKT). Those countries represent, however, 62\% of the FP7 funding in CIS 2008, 52\% in CIS 2010 and $58 \%$ in CIS 2012.

Figure 1: New to the market product innovations, by country

\section{CIS 2008}

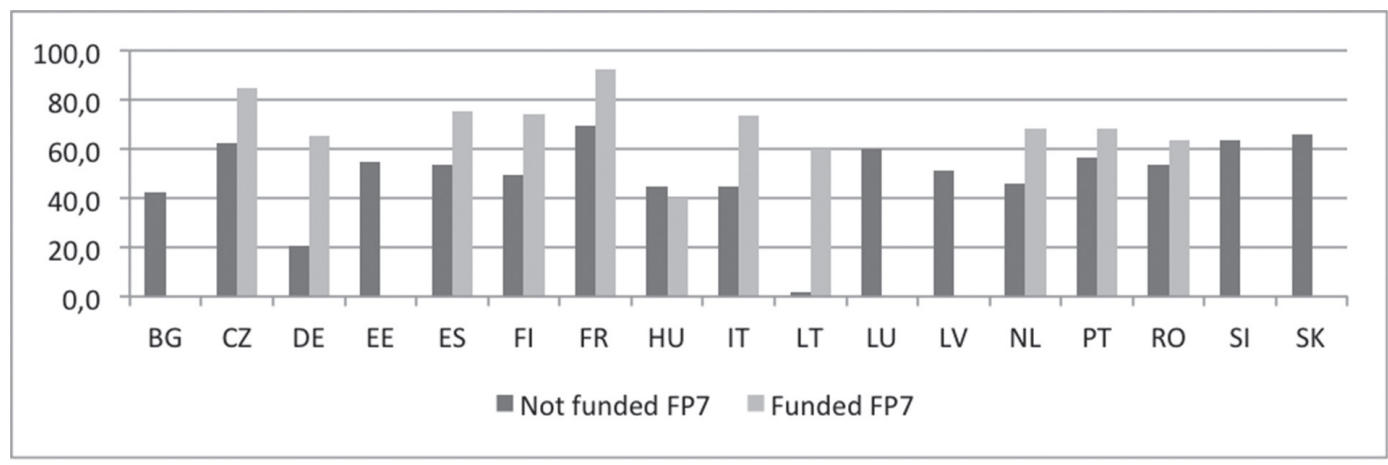

$\mathrm{N}: 13,277$ innovative enterprises not funded by FP7 (42.6\% of the total) and 1,047 enterprises funded by FP7 (73.9\% of the total)

\section{CIS 2010}

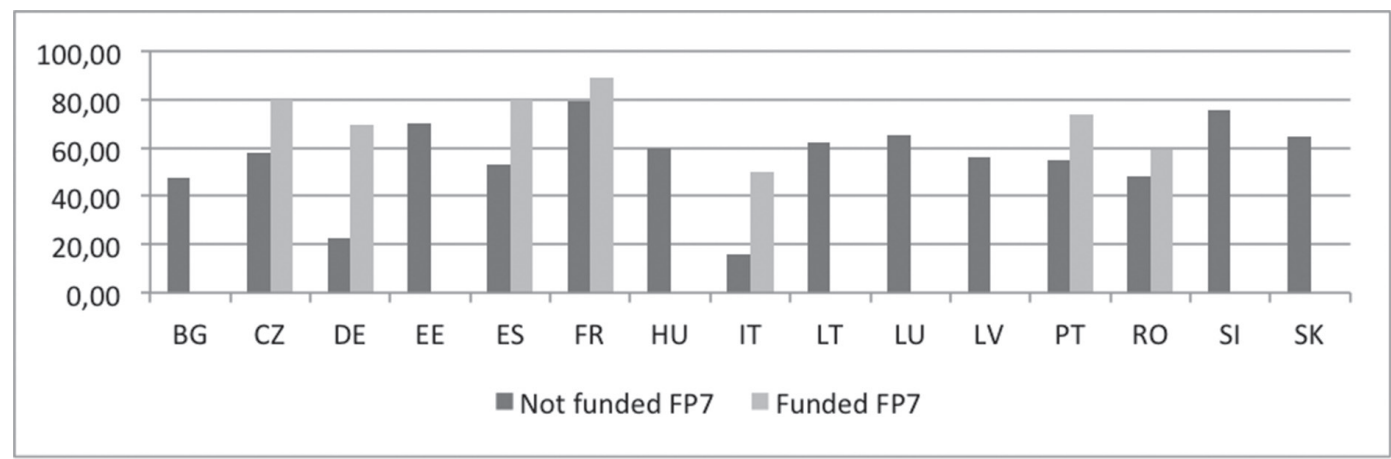

N: 10,194 innovative enterprises not funded by FP7 (43.5\% of the total) and 833 enterprises funded by FP7 (77.3\% of the total) 


\section{CIS 2012}

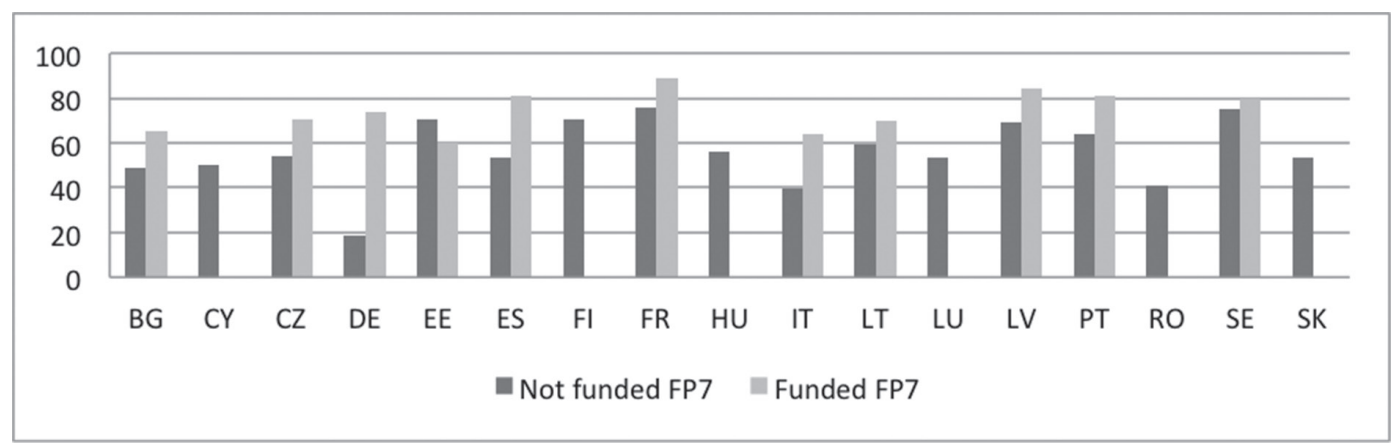

$\mathrm{N}: 11,492$ innovative enterprises not funded by FP7 (31.5\% of the total) and 996 enterprises funded by FP7 (77.6\% of the total)

Companies located in EU Member States like the Czech Republic, Spain, France or Portugal perform best in terms of introduction of new products or services to the market. Participation in FP7 has a statistically significant positive impact in all countries and all CIS editions.

Germany is an interesting case. In general, a low proportion of its firms say that they introduced new products to the market $24.7 \%$ in CIS 2008, 26.6\% in CIS 2010 and 22.5\% in CIS 2012). However, innovative firms from Germany supported by FP7 showed considerably higher figures $(65.7 \%, 69.7 \%$ and $73.7 \%$ respectively). These figures are two to three times higher than of those companies that did not receive FP7 support. In most countries, FP7 participation increases the performance of companies by $25 \%$ to $50 \%$.

It is also interesting to note that differences by countries are lower when referring to enterprises funded by FP7. Phi and contingency coefficients, even if statistically significant, are much lower: $22 \%-23 \%$ in CIS 2008 and CIS 2010, and even slightly under 20\% in CIS 2012. This may indicate that, in terms of introduction of new products or services to the market, FP7 also plays a cohesive role for innovative enterprises, as a consequence of collaborative Ryl activities.

These trends are not so evident when looking at the impact of FP7 participation on new to the firm innovations by country. FP7 involvement does not always make a difference for this sort of innovations. Again, the data suggest that innovative enterprises involved in FP7 tend to focus on new to the market novelties.

Due to confidentiality rules too many data are lost to analyse the variable "new to the market processes" (INPSNM).

\subsection{INNOVATION PERFORMANCE, BY SECTOR (NACE 1 DIGIT)}

Table 4 shows that the Manufacturing sector (NACE C) provides the majority of new to the market product innovations of the European economy, followed by Information and Communication (NACE J, around 10$14 \%$ ) and by "Wholesale, retail and repair of vehicles" and "Professional, scientific, technical activities" (NACE G and M respectively, slightly less than $10 \%$ each).The innovation performance of sectors is uneven, with statistically significant differences between them (Phi Coefficient and Contingency coefficient between $23 \%$ and $32 \%$, depending on the year).

Within innovative enterprises supported by FP7, NACE C, NACE M and NACE $\mathrm{J}$ cover alone $90 \%$ of the new products to the market. The manufacturing sector represents a share of more than $50 \%$, Scientific and technical services around $25 \%$ and ICT $12-14 \%$.

Even more interesting is to observe the gap in terms of innovation performance between companies not funded by FP7 and those that were. In the CIS 2008, $73.2 \%$ of the innovative manufacturing enterprises supported by FP7 introduced a product new to the market. This percentage grew to $79.4 \%$ in the CIS 2012. The figures are between 57\% and $84 \%$ higher than amongst enterprises that did not benefit from FP7 support.

In other sectors, the positive differences are even higher: $+78 \%$ to $+113 \%$ in the Scientific and Technical services sector, or even more than $+200 \%$ in NACE D, "Electricity, gas, air conditioned supply".

ICT enterprises were the most successful in terms of introduction of new products to the market. In CIS 2012, for instance, $56.3 \%$ of the ICT enterprises not supported by FP7 introduced a new product to the market, and $76.5 \%$ of those supported. The latter figure was even higher than $80 \%$ in previous CIS editions.

Similar trends appear for new to the firm innovations. Enterprises funded by FP7 perform much better than those not funded, in all sectors for which data are available. 
Table 4: New to the market product innovation, by sector

\begin{tabular}{|c|c|c|c|c|c|c|c|c|c|c|c|c|c|c|c|c|c|c|}
\hline \multicolumn{19}{|c|}{ CIS 2008} \\
\hline & NACE A & NACE B & NACE C & NACE D & NACE E & NACE F & NACE C & VACE & NACE I & NACE J & NACE K & NACE L. & NACE N & NACE I & NACE P & NACE 0. & NACE R & NACE S \\
\hline $\begin{array}{l}\text { Whole } \\
\text { economy } \\
\text { (\% by row) }\end{array}$ & 0.45 & 0.41 & 56.21 & 0.46 & 1.31 & 3.28 & 9.68 & 2.77 & 0.92 & 10.88 & 4.16 & 0.26 & 7.42 & 1.1 & 0.1 & 0.34 & & 0.19 \\
\hline $\begin{array}{l}\text { Funded FP7 } \\
\text { ( } \% \text { by row) }\end{array}$ & & & 50.97 & 1.5 & & 1.33 & 2.92 & 1.33 & & 13.07 & & 0 & 26.06 & & & & & \\
\hline $\begin{array}{l}\text { Not funded } \\
\text { by FP7 }\end{array}$ & 49.75 & 17.6 & 46.76 & 16.31 & 21.7 & 31.57 & 41.87 & 24.53 & 30.89 & 54.51 & 44.08 & 28.57 & 41.82 & 26.05 & 40.68 & 36.41 & 45.45 & 51.19 \\
\hline $\begin{array}{l}\text { Funded by } \\
\text { FP7 }\end{array}$ & & & 73.22 & 58.62 & & 62.5 & 63.46 & 44.12 & & 80.43 & & 0 & 78.67 & & & & & \\
\hline \multicolumn{19}{|c|}{ CIS 2010} \\
\hline $\begin{array}{l}\text { Whole } \\
\text { economy } \\
\text { (\% by row) }\end{array}$ & 0.46 & 0.42 & 57.29 & 0.4 & 1.4 & 2.94 & 8.67 & 2.36 & 0.16 & 12.11 & 3.75 & 0.1 & 7.94 & 0.71 & 0.22 & 0.68 & 0.14 & 0.26 \\
\hline $\begin{array}{l}\text { Funded FP7 } \\
\text { ( } \% \text { by row) }\end{array}$ & & & 53.85 & 1.78 & & & & 2.44 & 0 & 13.95 & & & 22.51 & & & & & \\
\hline $\begin{array}{l}\text { Not funded } \\
\text { by FP7 }\end{array}$ & 48.62 & 15.03 & 43.03 & 11.19 & 15.64 & 8.48 & 16.64 & 14.39 & 27.14 & 51.28 & 29.23 & 52.38 & 39.09 & 20.5 & 55.32 & 37.09 & 41.03 & 53.57 \\
\hline $\begin{array}{l}\text { Funded by } \\
\text { FP7 }\end{array}$ & & & 78.95 & 63.33 & & & & 65 & & 81.42 & & & 83.33 & & & & & \\
\hline \multicolumn{19}{|c|}{ CIS 2012} \\
\hline $\begin{array}{l}\text { Whole } \\
\text { economy } \\
\text { (\% by row) }\end{array}$ & 0.2 & 0.48 & 54.22 & 0.63 & 1.2 & 2.01 & 9.78 & 2.4 & 0.17 & 14.2 & 3.72 & & 9.73 & 0.41 & 0.11 & 0.5 & & 0.13 \\
\hline $\begin{array}{l}\text { Funded by } \\
\text { FP7 ( } \% \text { by } \\
\text { row) }\end{array}$ & & & 53.57 & 1.85 & 0.92 & & 2.43 & & 0 & 11.75 & & 0 & 25.44 & & & & & \\
\hline $\begin{array}{l}\text { Not funded } \\
\text { byFP7 }\end{array}$ & 48.61 & 28.1 & 47.1 & 18.65 & 22.45 & 31.56 & 41.94 & 22.23 & 42.86 & 56.28 & 37.33 & & 46.54 & 15.58 & 44.44 & 40 & 40 & \\
\hline $\begin{array}{l}\text { Funded by } \\
\text { FP7 }\end{array}$ & & & 79.35 & 61.11 & 50 & & 72.5 & & & 76.5 & & & 83.01 & & & & & \\
\hline
\end{tabular}

\subsection{ECO-INNOVATION}

CIS 2008 included a module on "innovation with environmental benefits". According to the survey, an environmental innovation is a new or significantly improved product (good or service), process, organisational method or marketing method that creates environmental benefits compared to alternatives. The definition includes also the following precisions:

- The environmental benefits can be the primary objective of the innovation or the result of other innovation objectives.

- The environmental benefits of an innovation can occur during the production of a good or service, or during the after sales use of a good or service by the end user.

This definition is voluntarily broad and highlights the multidimensional and systemic aspects of eco-innovation which can be seen as "a series of connected changes improving or creating novel functional systems that reduce use of natural resources and decreases the release of harm- ful substances across the whole life cycle" (European Commission 2015, p.11, based on ElO 2013). These specific characters of eco-innovation make it usually difficult to measure it notably through macro-indicators which tend to be mainly sectoral. Micro-data such as those made available through the CIS 2008 are therefore essential to facilitate the assessment of the private Ryl environmental performance in Europe. They offer tailored information which could be used notably in the context of Horizon 2020 and the European Commission's Circular Economy package which was published in 2015 .

Horizon 2020 is organised around "three mutually reinforcing priorities: (a) Excellent Science; (b) Industrial leadership; (c) Societal Challenges"25. Societal Challenges include environmental and climate-related actions, in line with the Europe 2020 strategy for a "smart, sustainable and inclusive growth", including sustainable agriculture, clean and efficient energy, green transport, climate action and resource efficiency, etc. Climate action and sustainability are overarching principles of Horizon 
2020. It is indeed expected "(...) that at least $60 \%$ of the overall Horizon 2020 budget should be related to sustainable development. It is also expected that climate-related expenditure should exceed $35 \%$ of the overall Horizon 2020 budget, including mutually compatible measures improving resource efficiency"26.

The Commission services monitor the funding of sustainable development and climate change, but what about the results of these investments? The CIS allows quantifying innovations with environmental benefits, such as materials or energy savings, reduced $\mathrm{CO} 2$ footprints, waste or water efficiency, etc. Of course, CIS 2008 refers to FP6/FP7 instead of Horizon 2020, but the data can at least give a flavour of the environmental impact of innovations supported by the FPs. It allows answering the following question: To what extent are innovations funded by FPs environmental-friendly?

To facilitate the analysis, the authors have created a new variable ECOTOT combining the nine questions referring to environmental benefits of innovations available in the CIS 2008 questionnaire (010.1). If respondents indicated at least one of these benefits proposed, ECOTOT would be positive. In other words, ECOTOT means "at least one environmental benefit of the innovation, either from the production of goods or services, or from the after sales use by the end user". This variable is then crossed by FUNRTD, as presented in Table 5.

Table 5: Environmental benefits of innovation (ECOTOT), by FP6/FP7 funding

\begin{tabular}{|l|c|c|c|}
\hline & $\begin{array}{c}\text { No } \\
\text { environmental } \\
\text { benefit }\end{array}$ & $\begin{array}{c}\text { Environmental } \\
\text { benefit }\end{array}$ & N \\
\hline Not funded by FP6/FP7 (\% by row) & $80.12 \%$ & $19.88 \%$ & 65,180 \\
\hline Funded by FP6/FP7 (\% by row) & $43.63 \%$ & $56.37 \%$ & 1,783 \\
\hline Total (\% by row) & $79.15 \%$ & $20.85 \%$ & 66,963 \\
\hline
\end{tabular}

Source: CIS 2008

The relationship is statistically significant (Phi coefficient $=14.5 \%$, Contingency coefficient $=14.3 \%$ ). Innovative companies supported by FP use to deliver more environmental-friendly products and services. They introduced almost three times more eco-innovations than enterprises that did not benefit from FP's support.

Figure 2 shows which sorts of eco-innovations are the most frequent ones. It is worth noting that multiple answers were possible: an ecoinnovation can have multiple kinds of benefits on environment.

Figure 2: Eco-innovations by type and by FP6/FP7 funding

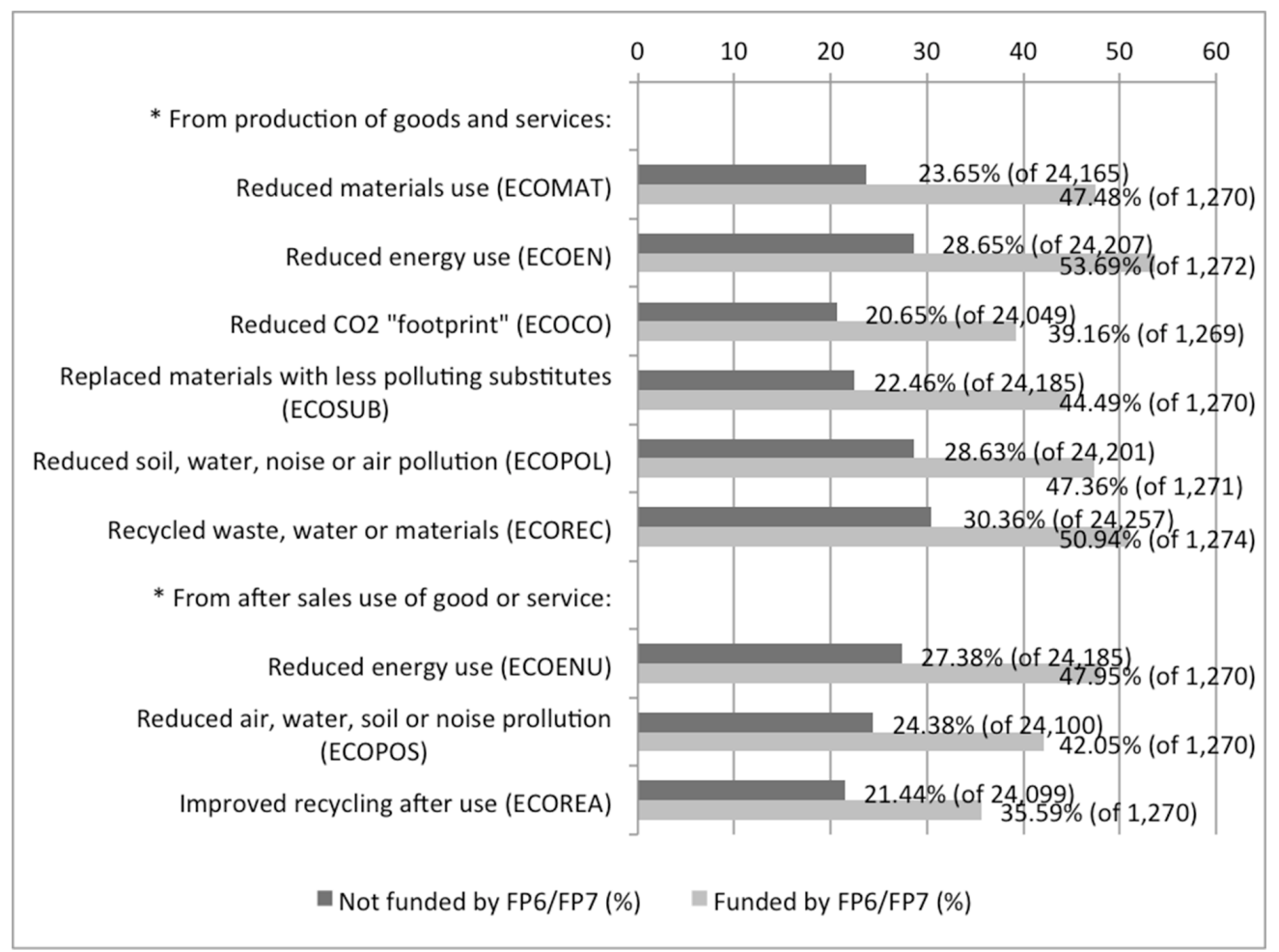


As regards the type of eco-innovation, the ranking is different amongst enterprises not funded by FP6/FP7 and amongst those that received the EU's R\&D support. The former tended to introduce innovations aiming at:

- recycling waste, water or materials $(30.4 \%)$,

- reducing energy and soil, water, noise or air pollution during the production $(28.7 \%-28.6 \%)$,

- saving energy during the use of the good or service (27.4\%)

Innovative enterprises funded by FP6/FP7 tended to introduce ecoinnovations aiming at:

- saving energy during the production (53.7\%),

- recycling of waste, mater or material during the production (50.9\%), and

- saving energy during the use (47.95\%).

Overall, environmental benefits during the production (i.e. to reduce costs) are dominant over those focused on the use of the final product or service $(18.4 \% / 52.9 \%$ versus $14 \% / 43.1 \%$ respectively).

Drivers of eco-innovation can be assessed trough question 010.2. The main reason that motivates eco-innovation is the existence of regulations and taxes $(24.7 \% / 44.7 \%$ for FP7 non-funded and funded firms respectively). Surprisingly, grants, subsidies or other financial incentives are the less often quoted factors. This is also true for FP6/FP7-funded companies (10.4\%/22.7\%). Voluntary codes or agreements, future regulations or market demand are mentioned by similar percentages of respondents (17-19\%/38-39\%).These observations confirm the results of the economic analysis carried-out by Horbach (2016): regulations and cost-savings are the main motivations of eco-innovation, while subsidies are relevant for innovations reducing $\mathrm{CO} 2$ emissions.

This type of analysis based on micro-data is a relevant way of assessing the effects of supply-side instruments on innovation with environmental benefits. Eco-innovation has a cross-cutting nature. The traditional macro-economic indicators largely based on sectors make it difficult to understand the private R\&I performance on environment. The CIS allows overcoming this difficulty. The data show that enterprises supported by the Framework Programme integrate better the environmental aspects in their innovations. Most innovations introduced by enterprises supported by FP6/FP7 have an environmental-friendly component. This allows an interesting conclusion. Even if FP6 and FP7 had not a societal challenge orientation as strong as Horizon 2020, the calls for proposals already focused on green or, at least, resource-efficient technologies. The CIS seems to confirm a positive impact of the Framework Programme from the environmental point of view. It demonstrates the systemic nature of eco-innovation: sustainability principles are largely embedded in the whole FP, and not only in specific themes or societal challenges.

\section{ECONOMIC IMPACT OF FP7 PARTICIPATION}

The CIS provides also data about the turnover of enterprises and about the percentage of such turnover coming from innovations, especially those new to the market (variable TURNMAR) and those only new to the firm (variable TURNIN).

This information allows to:

i. See whether there are significant differences in terms of turnover between enterprises funded by FP7 and those not funded.

ii. Observe the relative importance of innovation, in terms of turnover, for companies funded by FP7 and for enterprises not supported by the Framework Programme.

iii. Estimate the economic impact, always in terms of turnover, of FP7 funding.

Table 6 shows that there are very significant differences in terms of average turnover between companies funded by FP7 and those not funded. FP7 used to finance enterprises whose turnover is 12 to 14 times bigger. Standard deviations within each category are, of course, huge.

Table 6: Enterprises funded by FP7 vs. enterprises not funded: Differences in terms of average turnover

\begin{tabular}{|c|c|c|c|c|}
\hline CIS 2008 & $\begin{array}{c}\text { Turnover } 2006 \\
\text { (€ million) }\end{array}$ & $\begin{array}{c}\text { T-test } \\
\text { significance } \\
\text { (method) }\end{array}$ & $\begin{array}{l}\text { Turnover } 2008 \\
\text { (€ million) }\end{array}$ & $\begin{array}{c}\text { T-test } \\
\text { significance } \\
\text { (method) }\end{array}$ \\
\hline & 38.5 & \multirow{2}{*}{$\begin{array}{c}<0.0001 \\
\text { (Satterthwaite) }\end{array}$} & 45.7 & \multirow{2}{*}{$\begin{array}{c}<0.0001 \\
\text { (Satterthwaite) }\end{array}$} \\
\hline & 543.8 & & 614 & \\
\hline \multirow[t]{3}{*}{ CIS 2010} & $\begin{array}{l}\text { Turnover } 2008 \\
\text { ( } € \text { million) }\end{array}$ & $\begin{array}{c}\text { T-test } \\
\text { significance } \\
\text { (method) }\end{array}$ & $\begin{array}{c}\text { Turnover } 2010 \\
\text { (€ million) }\end{array}$ & $\begin{array}{c}\text { T-test } \\
\text { significance } \\
\text { (method) }\end{array}$ \\
\hline & 46.05 & \multirow{2}{*}{$\begin{array}{c}<0.0001 \\
\text { (Satterthwaite) }\end{array}$} & 43.1 & \multirow{2}{*}{$\begin{array}{c}<0.0001 \\
\text { (Satterthwaite) }\end{array}$} \\
\hline & 659.7 & & 643.6 & \\
\hline \multirow[t]{3}{*}{ CIS 2012} & $\begin{array}{c}\text { Turnover } 2010 \\
\text { (£ million) }\end{array}$ & $\begin{array}{c}\text { T-test } \\
\text { significance } \\
\text { (method) }\end{array}$ & $\begin{array}{l}\text { Turnover } 2012 \\
\text { (€ million) }\end{array}$ & $\begin{array}{c}\text { T-test } \\
\text { significance } \\
\text { (method) }\end{array}$ \\
\hline & 61.2 & \multirow{2}{*}{$\begin{array}{c}<0.0001 \\
\text { (Satterthwaite) }\end{array}$} & 66.6 & \multirow{2}{*}{$\begin{array}{c}<0.0001 \\
\text { (Satterthwaite) }\end{array}$} \\
\hline & 743.1 & & 814.4 & \\
\hline
\end{tabular}

These enormous differences are due to the fact that FP7 tended to support large enterprises (between $34 \%$ and $38 \%$, see table 2), while small SMEs represent around half of the companies not supported by FP7 in the survey (48.9\% in CIS 2008, 52.5\% in CIS 2010 and $48.25 \%$ in CIS 2012)

Table 7 shows the impact of innovation activities in terms of percentage of turnover, for both enterprises funded by FP7 and those not funded. Once again, we observe that innovative enterprises supported by the Framework Programme perform better, especially when they introduce new products to the market. Interestingly, the proportion of turnover coming from new to the market innovations increased from the CIS 2008 to the CIS 2012, both for enterprises supported by FP7 and, to a larger extent, for those not funded. 
Table 7: Percentage of turnover coming from innovations, funded by FP7 enterprises vs. non-funded

\begin{tabular}{|c|c|c|c|c|}
\hline CIS 2008 & $\begin{array}{l}\text { New to the market innovation } \\
\text { (\% turnover) }\end{array}$ & T-test significance (method) & $\begin{array}{c}\text { New to the firm innovation } \\
\text { ( } \% \text { turnover) }\end{array}$ & T-test significance (method) \\
\hline Not funded FP7 & 5.2 & \multirow{2}{*}{$\begin{array}{c}<0.0001 \\
\text { (Satterthwaite) }\end{array}$} & 8.1 & \multirow{2}{*}{$\begin{array}{c}0.0004 \\
\text { (Satterthwaite) }\end{array}$} \\
\hline Funded FP7 & 17.4 & & 15.4 & \\
\hline CIS 2010 & $\begin{array}{l}\text { New to the market innovation } \\
\text { (\% turnover) }\end{array}$ & T-test significance (method) & $\begin{array}{c}\text { New to the firm innovation } \\
\text { ( } \% \text { turnover) }\end{array}$ & T-test significance (method) \\
\hline Not funded FP7 & 8.5 & \multirow{2}{*}{$\begin{array}{c}<0.0001 \\
\text { (Satterthwaite) }\end{array}$} & 12.2 & \multirow{2}{*}{$\begin{array}{c}<0.0001 \\
\text { (Satterthwaite) }\end{array}$} \\
\hline Funded FP7 & 18.7 & & 15.4 & \\
\hline CIS 2012 & $\begin{array}{l}\text { New to the market innovation } \\
\text { (\% turnover) }\end{array}$ & T-test significance (method) & $\begin{array}{c}\text { New to the firm innovation } \\
\text { ( } \% \text { turnover) }\end{array}$ & T-test significance (method) \\
\hline Not funded FP7 & 10.8 & \multirow{2}{*}{$\begin{array}{c}<0.0001 \\
\text { (Satterthwaite) }\end{array}$} & 15.7 & \multirow{2}{*}{$\begin{array}{c}0.69 \\
\text { (Satterthwaite) }\end{array}$} \\
\hline Funded FP7 & 19.1 & & 15.4 & \\
\hline
\end{tabular}

Instead, the percentage of turnover from new to the firm innovations remained stable for the FP7-funded sub-sample, while other enterprises increased their figure overtime. In the CIS 2012, the differences between the two groups are statistically insignificant.

This trend, to be confirmed in CIS2014, may indicate a positive evolution of European enterprises towards innovation activities.

To estimate the economic impact of innovation activities, the authors have created new variables based on each CIS survey data:

- TURMAREUR: Turnover coming from new or significantly improved products introduced to the market, in euros. It results from TURNMAR * TURN08 (for CIS 2008; TURNMAR * TURN10 for CIS 2010 and TURNMAR * TURN12 for CIS 2012).

- TURNINEUR: Turnover coming from new or significantly improved products to the firm only, in euros, calculated by analogy (e.g. TURNIN * TURN08).
- TOTTURNEUR: Turnover coming from new or significantly improved products to the market or to the firm only, in euros, i.e. TURNMAREUR + TURNINEUR.

Table 8 compares the results of companies funded by FP7 with those not funded. Again, differences between the two categories of enterprises are statistically significant - and huge. However, as shown by the previous tables, such differences are the result of a "size effect" (FP7funded innovators use to have a much higher turnover, mainly due to their size) and a "turnover effect", as well as the interaction of those variables. This is confirmed by two-ways ANOVA between the variables size of enterprise, FP7 support (FUNRTD) and each of the three variables newly created, in CIS 2008, CIS 2010 and CIS 2012 (see Annex 3). The means suggest that the "size effect" is stronger than the "turnover effect".

Table 8: Average turnover coming from innovations, funded by FP7 enterprises vs. non-funded, in euro

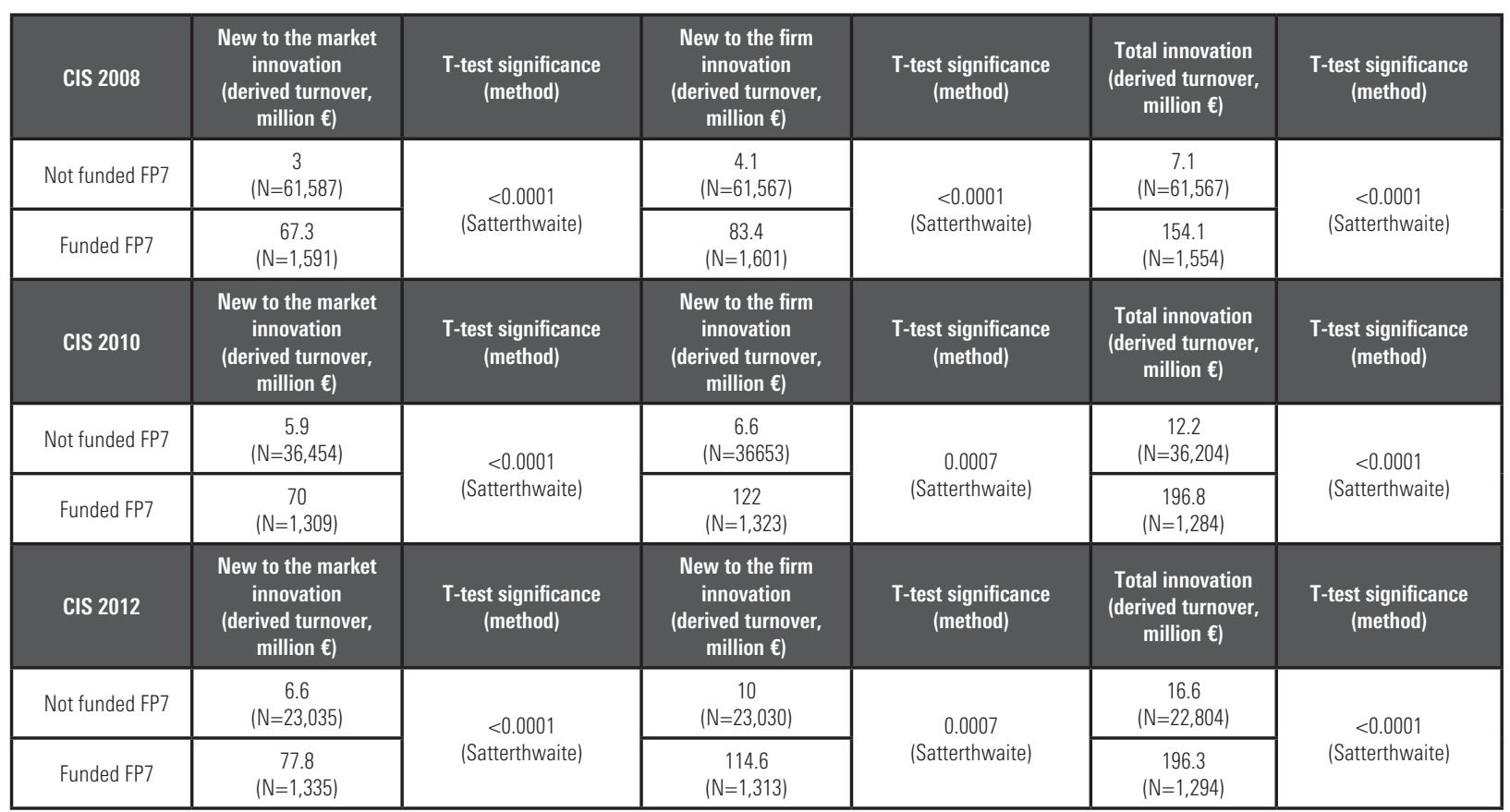




\section{CONCLUSIONS}

The European Commission expends large amounts of money in studies aimed at evaluating the Framework Programmes and their impacts. Only the evaluation studies launched for the preparation of the Interim Evaluation of Horizon 2020 sum-up a budget of $€ 1.5$ million - and this figure does not include the evaluation actions carried-out at thematic level (e.g. for each Horizon 2020's Societal Challenge, Leadership in Enabling and Industrial Technologies, etc.), which represent at least 14 studies more, conducted mainly through public procurement or expert groups. The ongoing evaluation activities include, for instance, an "Expert Group on evaluation methodologies for the interim and ex-post evaluations of Horizon 2020", with a budget of $€ 0.7$ million. With this ambitious study, the Commission seems to implicitly recognise that, despite the significant improvements in recent years, the evaluation and monitoring system of the Framework Programmes still requires new approaches and sources of evidence.

One of the most critical areas for the evaluation of Horizon 2020 remains the impact on innovation. It is particularly relevant in the current political context: innovation is considered a critical driver to create growth and jobs, and there are increasing pressures to guarantee that public investments are accountable and successful. Therefore the ongoing Horizon 2020 could be an opportunity to better collect and measure innovation outputs and outcomes. Few innovation-related indicators are collected directly from projects: only patents, prototypes and testing activities and, for the industrial leadership part of the programme, the share of participating firms introducing innovations new to the company or to the market. This is clearly insufficient and obliges the Commission services to use very complex econometric models, based on several assumptions and disconnected from actual projects' outputs, to estimate the economic impact of the programme (see for instance Martinuzzi et al. 2015, pp.59-60).

This paper demonstrates that the Eurostat's Community Innovation Survey is a very valuable source of information to assess and quantify the impact of the Framework Programme on innovation.

Innovation performance of FP7-funded innovative enterprises and their characteristics

The CIS data show that innovative enterprises supported by FP7 perform better than those not financed by the programme:

- Between $73 \%$ and $80 \%$ of them introduced new products or services to the market, compared with $32 \%$ to $43 \%$ of innovative companies not financed by FP7.

- Between $67 \%$ and $71 \%$ introduced products or services new to the firm only, compared with $42 \%$ to $59 \%$ of innovative companies not financed by FP7.

- Between $39 \%$ and $49 \%$ introduced processes new to the market, while the figures are $13 \%$ to $20 \%$ amongst of innovative companies not financed by FP7.

These data show that FP7-funded innovative enterprises performed best in exploiting new to the market products or services - especially compared with products and services that are just new to the firm.
The CIS data permit also to characterise the FP7-funded enterprises that exploited their innovations on the market:

- Large innovative firms perform better in introducing products and services that are new to the market. Differences are in most cases statistically significant, but not that high (e.g. in CIS 2008, $79 \%$ of large innovative enterprises funded by FP7 introduced a new product or service to the market, while the figure for SMEs was around 70\%; the gap is lower in successive CIS editions).

- The country where enterprises are based influences more the introduction of new products, services or processes to the market or new to the firm than the size of enterprises. The Czech Republic, Spain, France or Portugal perform best in terms of introduction of new products or services to the market. Participating in FP7 has always a statistically significant positive impact. In Germany, for instance, the gap between FP7-funded and not funded enterprises is very significant, ranging from $23 \%-27 \%$ (non FP-funded) to $66 \%$ to $74 \%$ (FP funded). In most cases, FP7 participation increases the performance of companies by countries by $25 \%$ to $50 \%$.

- The differences in terms of innovation performance between countries are lower when the companies are supported by FP7. This suggests a cohesive role of the Framework Programme for innovative enterprises as a consequence of collaborative Rql activities.

- The Manufacturing sector (NACE C) provides the majority of new to the market product innovations of the European economy, followed by Information and Communication (NACE J, around $10-14 \%$ ) and by "Wholesale, retail and repair of vehicles" and "Professional, scientific, technical activities" (NACE G and $M$ respectively, slightly less than $10 \%$ each). Amongst innovative companies supported by FP7, the sectors Manufacturing, Professional and scientific activities, as well as ICT cover 90\% of the new products to the market. The manufacturing sector represents a share of more than $50 \%$, Scientific and technical services around $25 \%$ and ICT 12-14\%. However ICT enterprises were the most successful in terms of introduction of new products to the market.

- Based on the CIS 2008 only, innovative companies supported by FPs delivered more environmental-friendly products and services. They introduced almost three times more eco-innovations $(+183.5 \%)$ than enterprises that did not benefit from FP's support.

The CIS shows also that participation in FP7 has a positive economic impact measured in terms of turnover. Innovative firms supported by FP7 present a proportion of sales of new to the market products twice or three times higher than companies not funded by the Framework Programme. The paper calculates what this represents in euros, but the amounts are heavily influenced by the size of (some) enterprises that received FP7 support.

27 Horizon 2020 - Work Programme 2016-2017, section 19 (Dissemination, exploitation and evaluation). European Commission Decision C(2016)4614 of 25 July 2016, at: http://ec.europa.eu/research/participants/data/ref/h2020/wp/2016_2017/main/h2020-wp1617-comm-diss_en.pdf 
CIS issues to assess the innovation impact of the Framework Programmes

The CIS also presents caveats that limit its capacity to evaluate the evaluation impact of the Framework Programme: geographical coverage of publicly available data, years of reference that do not exactly coincide with the FPs' timeframe, etc. The analysis of the data has shown that main issues are linked with and limited by the questionnaire design and confidentiality rules:

- The question that allows identifying enterprises supported by FP7 comes from a previous filter. Enterprises that are not involved in innovation activities do not answer such question. This means that the FUNRTD variable, key to assess FP7, covers "FP7 innovators" only, i.e. enterprises that carry-out innovation activities and received an FP7 grant. We cannot assume that all private for profit organisations supported by the Framework Programme are involved in innovation and FUNRTD cannot be considered a priori a sub-sample of FP7 participants. This makes extrapolating results to the overall FP impossible.

- Indeed, also due to the position of the question on FP7 support, marketing and organisational innovations are excluded (OECD 2015). "FP7-innovators" cover product, service and/or process innovations only, which does not cover the whole spectrum of possible innovations.

- The confidentiality rules imply that, when we cross more than two variables (e.g. FUNRTD and sector, or country), information for some categories is lost. The results are then incomplete and, indeed, more detailed data, for example by NACE 2 or 3 digits become unavailable.

Of course, one major issue is that correlations do not mean causality. The CIS data demonstrate that FP7-funded innovative enterprises perform better, but this does not mean that it is thanks to FP7. It can be argued that FP7 attracted the most innovative enterprises, which also benefit from international R\&l cooperation financed by the EU, amongst other factors. This is however a problem that can hardly be solved.

Despite its caveats, the CIS is a gold mine for Ryl policy and should be further exploited by the Commission services. It provides quantitative data on impacts of Ryl on innovation, measured in terms of exploitation: products, services or processes new to the market and/or to the firm, as well as the turnover obtained caused by the introduction of new products, services and processes. Even if the data are incomplete or not detailed enough (for example, to analyse the specific impacts by FP7-Cooperation Theme or Horizon 2020-Societal Challenge), important information is provided.

In addition, the CIS data are accessible for free by research entities and are easy to use with a basic statistical knowledge. The analysis that is presented in this paper is indeed based on simple cross-tables (contingency tables, t-tests and ANOVAs), trying to respect the parsimony principle and making the results as easy to understand as possible.

\section{REFERENCES}

\section{LITERATURE}

Arundel, Anthony (2007) 'Innovation survey indicators: what impact on innovation policy?". In: OECD (ed.) Science, Technology and Innovation Indicators in a Changing World. Responding to Policy Needs. Paris: OECD.

Connolly, Niam et al. M.(2014) Ex-Post Evaluation of FP7, Cooperation Programme Theme: "Environment (including Climate Change). Brussels: European Commission. At: http://bookshop.europa.eu/en/ex-post-evaluation-of-fp7-cooperation-programme-theme-environment-includingclimate-change--pbKI0614224/

Eco-Innovation Observatory (EIO, 2013) A systemic perspective on ecoinnovation. Brussels: European Commission/ElO Thematic Report.

European Commission (2015) From Niche to Norm. Suggestions by the Group of Experts on a 'Systemic Approach to Eco-Innovation to achieve a low-carbon, Circular Economy'. Brussels: European Commission.

Eurostat (2008) NACE Rev. 2. Statistical classification of economic activities in the European Community. Luxembourg: OPOCE.

Fisher, Robbert; Polt, Wofgang and Vonortas, Nicholas (2009) The impact of publicly funded research on innovation: An analysis of European Framework Programmes for Research and Development. Luxembourg: OPOCE.

Hassan, Emmanuel et al. (2013) Testing Horizon 2020 performance indicator on SMEs involved in innovation projects under FP7. Brussels: Science-Metrix, produced for the European Commission, DG Research and Innovation.

Horbach, Jens (2016) 'Empirical determinants of eco-innovation in European countries using the Community Innovation Survey'. Environmental Innovation and Societal Transitions, Vol. 19, pp.1-14.

Joint Research Centre (various editions) EU Industrial Scoreboard reports. Brussels: European Commission, Joint Research Centre. At: http:// iri.jrc.ec.europa.eu/scoreboard.html

Martinuzzi, André et al. (2015)Commitment and Coherence, essential ingredients for success in science and innovation. Ex Post Evaluation of the 7th Framework Programme (2007-2013). Brussels: European Commission. At: http://ec.europa.eu/research/evaluations/pdf/fp7_final_ evaluation_expert_group_report.pdf\#view=fit\&pagemode=none

Mazzanti, M. et al. (2016) 'Firm surveys relating Environmental Policies, Environmental Performance and Innovation. Design challenges and insights from empirical application', OECD Environment Working Papers No. 103. Paris: OECD. At: http://www.oecd-ilibrary.org/environment/ firm-surveys-relating-environmental-policies-environmental-performance-and-innovation_5jm0v405I971-en?crawler=true 
Muldur, Ugur. et al. (2006) A New Deal for and Effective European Research Policy. The design and impacts of the 7th Framework Programme. Dordrecht: Springer.

OECD (2015) Oslo Manual. Guidelines for collecting and interpreting innovation data. Paris: OECD.

\section{OFFICIAL DOCUMENTS}

Decision 1982/2006 of the European Parliament and the Council of 18 December 2006 concerning the Seventh Framework Programme of the European Community for research, technological development and demonstration activities (2007-2013). At: http://cordis.europa.eu/documents/documentlibrary/90798681EN6.pdf

Communication from the European Commission (2008) A European Economic Recovery Plan, COM (2008)800 final. At: http://ec.europa.eu/economy finance/publications/publication13504 en.pdf

Communication from the European Commission (2010) Europe 2020: A strategy for smart, sustainable and inclusive growth, COM (2010)2020 final. At: http://ec.europa.eu/eu2020/pdf/COMPLET\%20EN\%20BARROS0\%20\%20\%20007\%20-\%20Europe\%202020\%20-\%20EN\%20version. pdf

Communication from the European Commission (2010) Europe 2020 Flagship Initiative Innovation Union, COM (2010) 546 final. At: http:// bookshop.europa.eu/en/ex-post-evaluation-of-fp7-cooperation-programme-theme-environment-including-climate-change--pbKI0614224/

Commission Staff Working Document accompanying the Communication from the Commission 'Horizon 2020 - The Framework Programme for Research and Innovation', SEC(2011)1487 final. At: http://ec.europa. eu/research/horizon2020/pdf/proposals/horizon 2020 impact assessment report.pdf

Regulation 1291/2013 of 11 December 2013 of the European Parliament and the Council establishing Horizon 2020 - the Framework Programme for Research and Innovation (2014-2020). At: http://eur-lex.europa.eu/ LexUriServ/LexUriServ.do?uri=0J:L:2013:347:0104:0173:EN:PDF

Council Decision of 3 December 2013 establishing the specific programme implementing Horizon 2020 - the Framework Programme for Research and Innovation (2014-2020). At:

Communication from the European Commission (2015) Closing the loop - An European action plan for the Circular Economy, COM(2015) 614 final. At: http://eur-lex.europa.eu/legal-content/EN/ TXT/?uri=CELEX:52015DC0614

Communication from the European Commission (2016) Communication on the Response to the Report of the High Level Expert Group on the
Ex Post Evaluation of the Seventh Framework Programme, COM (2016)5 final. At: https://ec.europa.eu/research/evaluations/pdf/archive/fp7-expost evaluation/commission_communication_1 en act part1.pdf

Horizon 2020 - Work Programme 2016-2017, section 19 (Dissemination, exploitation and evaluation). European Commission Decision C(2016)4614 of 25 July 2016, at: http://ec.europa.eu/research/participants/data/ref/ h2020/wp/2016 2017/main/h2020-wp1617-comm-diss en.pdf

\section{AUTHORS}

\section{corresponding author: \\ JESÚS ALOUÉZAR SABADIE}

European Commission - DG Research and Innovation

CDMA 3/175

1049 - Brussels (Belgium)

e-mail: jesus-maria.alquezar-sabadie@ec.europa.eu

\section{CLAIRE KWIATKOWSKI}

European Commission - DG Research and Innovation

\section{ACKNOWLEDGEMENT/DISCLAIMER}

This paper is based on data from Eurostat's Community Innovation Survey, editions 2008, 2010 and 2012. It reflects the views only of the authors; neither the European Commission nor any person acting on behalf of the Commission is responsible for the use which might be made of the following information. The responsibility for all conclusions drawn from the data lies entirely with the authors.

The authors would like to thank Geneviève Villette (Eurostat) for her valuable support, as well as the different people who read, reviewed and commented the paper.

\section{STATISTICAL ANNEX}

Please find the statistical annex for this paper on the following website: http://repository.fteval.at/id/eprint/305 